\title{
Academic library postcards
}

\author{
By Billy R. Wilkinson \\ Director, Albin O. Kuhn Library \& Gallery \\ University of Maryland, Baltimore County
}

\section{Exterior views from pioneer to contemporary.}

Editor's Note: "A country of collectors!" That's how a recent British visitor described the United States. He was most impressed with meeting so many Americans who were serious (even frenzied) collectors of everything from crystal celery vases to library postcards. He asked Billy Wilkinson about the latter mania and the Editor asked him to share his information on academic library postcards in two articles. The second will appear in a few months and be devoted to library interiors as shown on the cards.

Collectors of library postcards have been more openly admitting their pursuit of these elusive ephemera in recent years thanks to the delightful Norman Stevens, director of libraries at the University of Connecticut. Dr. Stevens invited the collectors out of the closet and to a public forum entitled "Images of Librarianship: What Collecting Librariana Can Tell Us about Library History" at the 1982 American Library Association Annual Conference. The six speakers were well reviewed in the library press. ${ }^{1}$ Two made remarks on postcards.

The elegant exhibition "Carnegie's Libraries: A Sesquicentennial Celebration" in 1985 at the Cooper-Hewitt Museum in New York City was yet another major milestone of recognition for postcard collectors. Many vintage library postcards from the extensive Norman Stevens collection were

1،"The Balancing Act: A Report on the 101st Annual Conference of the ALA," Library Journal 107 (September 1, 1982): 1608. featured in the survey of the more than 1,600 free public libraries built with Carnegie funding.

Stevens continued to add renown to library postcard collectors with the publication in 1986 of his Guide to Collecting Librariana (Scarecrow Press, 166 pages). Along with material on badges, postage stamps, rubber stamps, shopping bags, Tshirts, and other ephemera, he provided a bibliography and guide for beginning collectors as well as articles by others on such topics as the messages written on library postcards.

\section{Views of academe}

Turning to academic library postcards, what do we find? If we begin by quantifying, academic cards come in a definite second to public library cards. In the author's collection of 5,205 library postcards, there are 156 Boston Public Library cards and 158 New York Public Library ones. (The Library of Congress cards number 305 in this particular collection and finish in first place.) In Judith E. Holliday's collection of more than 3,050 postcards, there are 75 Boston Public Library, 48 New York Public Library, and 108 Library of Congress.

The winner from academe in the author's collection is the Low Library at Columbia University with 57 postcards. They show that magnificent McKim, Mead \& White building by light of day in 56 instances (see cover) and by moonlight on one fanciful card. Two cards have had sparkling glitter glued on by some anonymous hands to outline someone's idea of the dimensions of Low Library's splendor. In contrast, there are only eight postals of 
the Butler Library at Columbia in the author's collection. The Holliday collection has 38 Low Library postcards and 2 Butler Library ones.

The 1890 Cornell University Library with its distinctive clock tower (now renovated and renamed the Uris Undergraduate Library and the Jennie McGraw Tower) with 41 different cards is in second place for academe in the author's collection. (This, however, may be due to the fact that he lived in Ithaca and worked at Cornell for eight years and still visits there and shops for cards in the Cornell Bookstore.) Yale University's Beinecke Rare Book and Manuscript Library is represented by 23 cards. The Sterling Memorial Library is seen on 14 cards. When one counts the "Old Library" (see cover), the "New Library," and the Cross Campus Library, Yale is represented by an additional ten cards for a total of 47 postals of its libraries.

For comparison, the Holliday collection has $\mathbf{1 6}$ postcards of the 1890 Cornell Library, 23 of Yale's Beinecke, 11 of the Sterling Memorial Library, and a total of 40 postcards of Yale's libraries.

Other random quantities in the author's collection from about the country: Doe Library, University of California at Berkeley, 12; Widener Library at Harvard, 11; Harper Memorial Library, University of Chicago, 10; University of Illinois at Urbana-Champaign, 8; General Library at the University of Michigan, 8; Lilly Library, Indiana University, 6; University of Nebraska Library in Lincoln, 5; and Anderson Memorial Library, College of Emporia, Kansas, 4.

But numbers do not have to do with quality and variety. What kinds of academic library postcards are there? Just as there are pioneer viewcards (including private mailing cards), later and contemporary viewcards, cards showing political and social history, advertising postcards, sets, signed artists, "greetings from," linens, photographic cards, and novelties as the main categories of regular postcards, academic library postcards may be similarly categorized.

According to Dorothy Ryan, picture postcards really began in the United States with the souvenir issues available in 1893 at the World's Columbian Exposition in Chicago. These are not, however, the earliest commercially produced picture postcards. Ryan believes the first private (not government issued) postcard in the U.S. was copyrighted on December 17, 1861, by J.P. Charlton and published in Philadelphia by H.L. Lipman. ${ }^{2}$

"Pioneers" are those cards published, but not necessarily mailed, before the Act of Congress of May 19, 1898, which intended to allow, effective July 1,1898 , privately printed postcards the same postal privileges as the cards issued by the Federal government (privately printed cards had required two cents postage instead of one cent on the government cards). An example from the author's collection of an academic pioneer which is a private mailing card is the University of Illinois (see Figure 1). One wrote the message on one side along with the picture of the building and on the verso there was space for the name and address of the correspondent.

${ }^{2}$ Dorothy B. Ryan, Picture Postcards in the United States, 1893-1918 (New York: Clarkson N. Potter, 1982), 1.

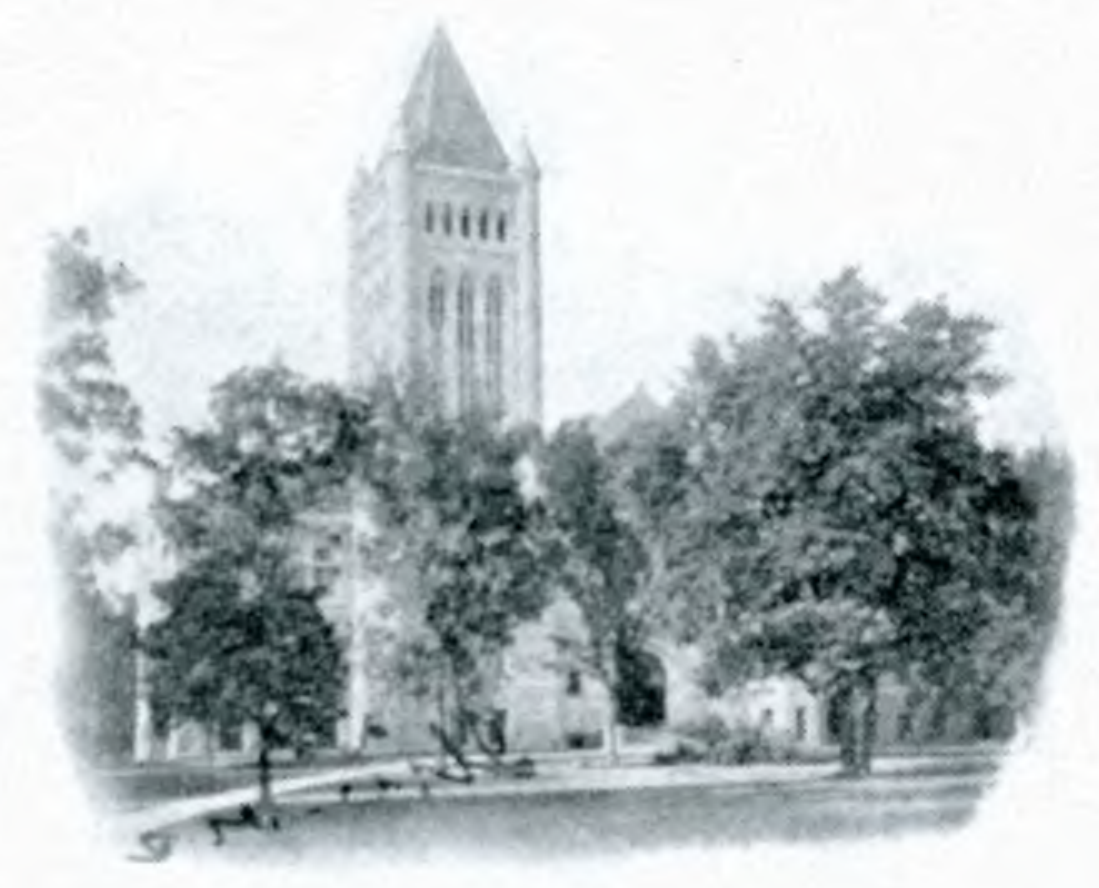

LIBRARY BULLING;

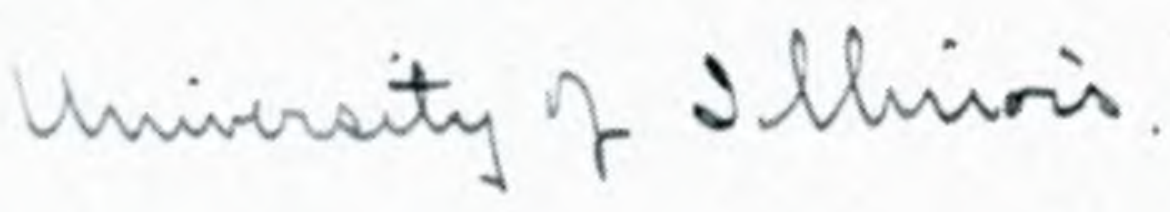

Fig. 1. The University of Illinois Library. 
Viewcards from the 1890s to the most contemporary are myriad in number. Surely, viewcards are the majority of postcards published in the U.S. and library viewcards are also myriad. An attractive contemporary card recently mailed to the author is the Chester Fritz Library at the University of North Dakota (see Figure 2).

There are many regular postcards which show political and social history (presidential campaigns, wars, suffrage, prohibition, etc.). However, the author's collection contains no academic library postcards displaying political or social history. Does anyone have a postcard mailed by a candidate for ACRL president asking for your vote?

All library postcards are in one sense advertising cards. The academic library postal was and may still be a way to market the library and the campus to prospective students, parents, and others. A contemporary advertising card is that of the Albin $\mathrm{O}$. Kuhn Library \& Gallery, University of Maryland Baltimore County. On the front is a photograph of the building (see Figure 3 ) and on the verso is a list of present and future exhibitions in the gallery. There are more specialized advertising cards marketing shelving and bookmobiles, particularly to public libraries.

From 1905 to 1915 when postcard collecting may have been at its peak, publishing firms sought to sell collectors sets of cards (ranging from U.S. presidents and state capitols to women represent- ing states, nations, cities, and colleges). Among public libraries, sets of cards showing the murals of the Boston Public Library are a good example. In the author's collection, there is only one set of cards which pertain to academe. The "Memorial Postcard Series by Wisconsin Library Workers" features the 1900 graduating class at the University of Illinois (see Figure 4) as well as other academic cards (portraits of Margaret E. Monroe and others).

Signed artists cards range from Howard Chandler Christy and his romantic drawings of American women to Frederick Burr Opper and his lighthearted cartoons of Alphonse and Gaston as well as biting political satire. ${ }^{3}$ Searching the author's collection failed to produce any signed artists academic postcards.

Next to viewcards, surely the type of card most frequently found in general collections is "Greetings From...." We all have sent and received these postals. Although it does not send you greetings, Figure 5 is one of my favorites with this motif: "The Chicago Public Libraries" with the Harper Memorial Library at the University of Chicago on the cover of a book, along with the Chicago Public Library, the Newberry Library, and the John Crerar Library. The text on the card's verso reads: "Chicago Public Libraries. Pictured you see the four

${ }^{3}$ Ryan, Picture Postcards, 207.

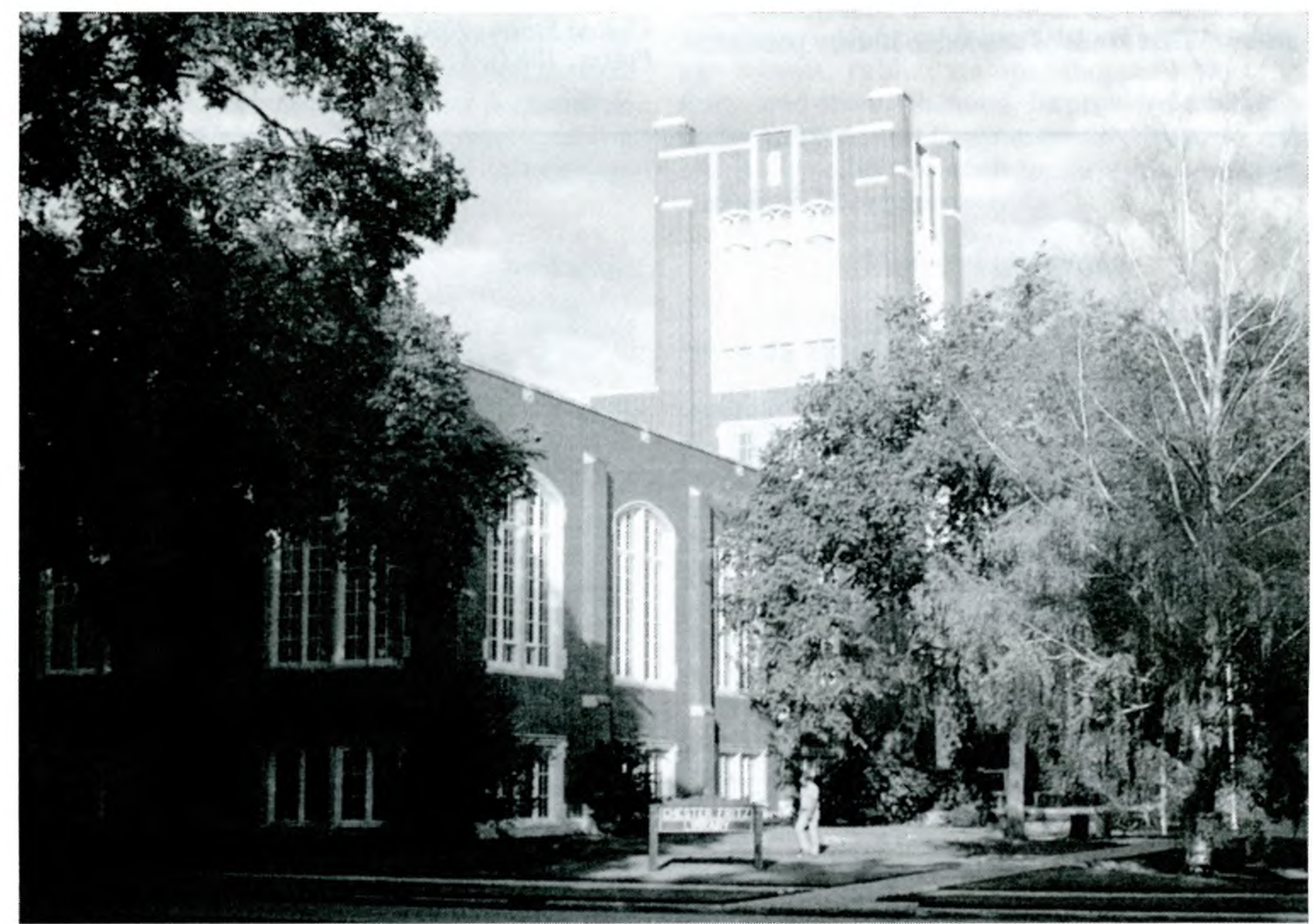

Fig. 2. The Chester Fritz Library at the University of North Dakota. 


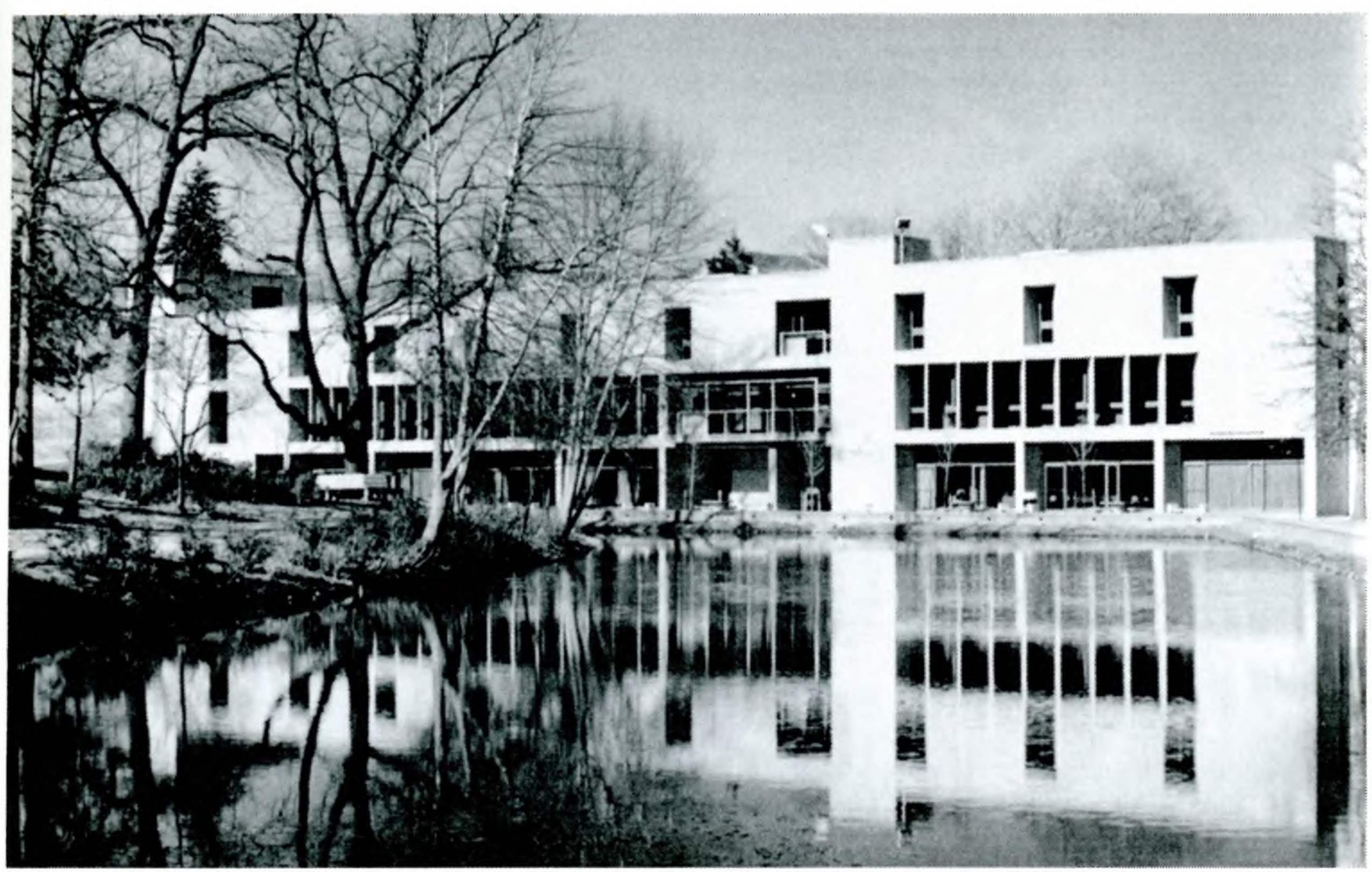

Fig. 3. The Albin O. Kuhn Library and Gallery, University of Maryland, Baltimore County.

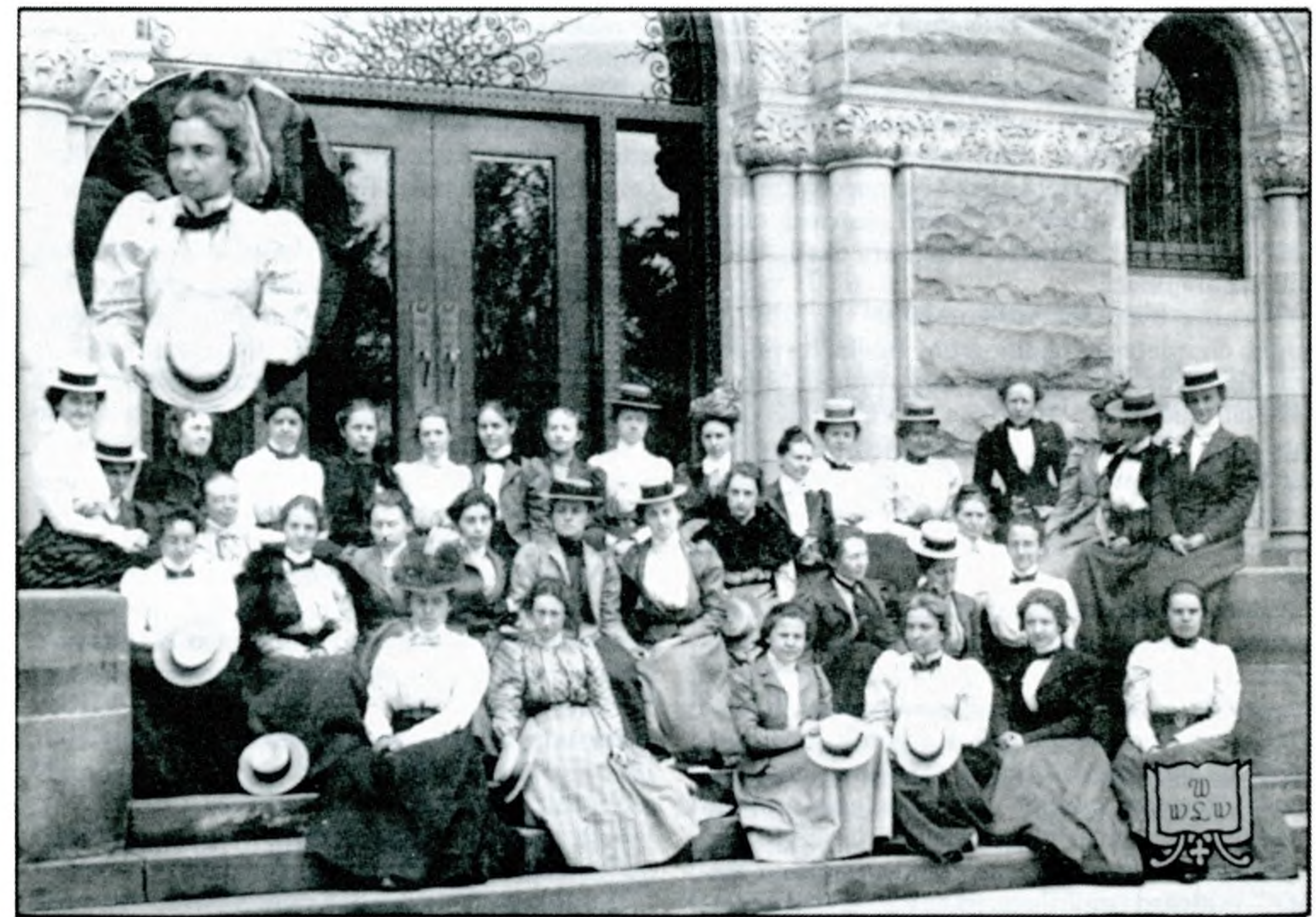

Fig. 4. Library science graduating Class of 1900, the University of Illinois, with inset of Minnie Earl Sears (Muriel Fuller Memorial Series, no. 1, by Wisconsin Women Library Workers). 


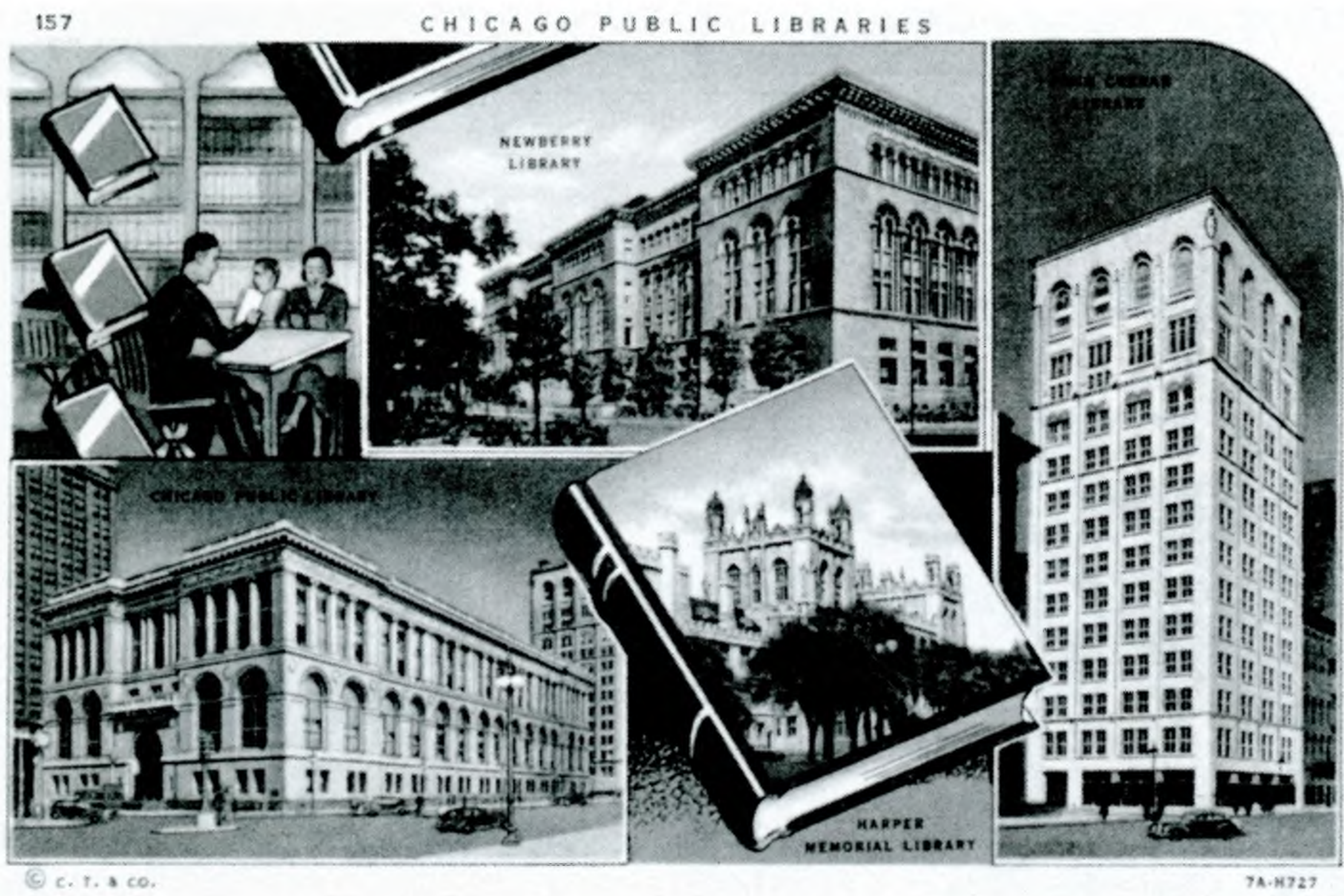

Fig. 5. Chicago libraries.

leading Libraries in Chicago. The Chicago Public Library, Harper Memorial Library, John Crerar Library and the Newberry Library. Chicago is truly a bookish town." This postal is also a linen card.

Or are linen postcards the most common of all? These grainy, slightly unpleasant cards, often with a bad yellow border, seem much too numerous! This, however, is probably an erroneous impression on the author's part. Of the 57 postcards of the Low Library at Columbia University cited above, only six are linens.

Turning from the ridiculous to the sublime might characterize going from linens to photographic cards. Hal Morgan and Andreas Brown have chronicled the American photographic postcard from 1900-1920 in their Prairie Fires and $\mathrm{Pa}$ per Moons (Boston: David R. Godine, 1981). They could have included the Stanford Library and Hoover Tower (see Figure 6) among their examples.

What is a greater delight for a collector than finding a novelty card to add to his academic library collection? The author's novelty catches, so far, are the cards of the Low Library and others to which anonymous but delicate hands have outlined the buildings in tinsel. (Tinseling glue and special "jeweling outfits" were available to decorate postals at home. $\left.{ }^{4}\right)$ But the author is still fishing in the flea markets of the world for a "hold-to-thelight" postcard (multilayered cards on which certain parts of the top layer have been cut out so that

${ }^{4}$ Ryan, Picture Postcards, 249. when held to the light the cut portion, usually windows, the sun or moon or stars, appear realistically illuminated). Or to haul in a leather or wood card. $\mathrm{O}$ that one of these novelties would be of an academic library!

After counting and categorizing, what's still to be done in this very brief excursion into the realm of exterior views of academic libraries? Appraise their value and condition. Read their messages. View and enjoy them.

The value of postcards in general as well as all collectibles seems to be increasing greatly. Tin Type, the publication of the Tin Container Collectors Association, bemoans the auction price of $\$ 9,000$ for a Dr. Pepper dispenser and $\$ 13,000$ for a Buster Brown shoe-store sign. ${ }^{5}$

Ed Marks, the editor of The Ice Screamer, also worries about the "dramatically escalating prices of all collectibles and our concern for the future of collecting for those with limited dollars to spend."

In late 1984, Postcard Collector recorded that in "a private sale earlier this year, the most expensive postcard-the postcard reproduction of Mucha's advertising poster for Waverly Cycles-changed ownership for $\$ 4,400 ., 7$

Scanning other issues of Postcard Collector from 1984 to date, one finds "a strong demand for mid-

\footnotetext{
${ }^{5}$ Nosmo King, "Nosmo's Trip to No Hope," The Ice Screamer, no. 37 (August 1988): 4.

${ }^{6}$ Ed Marks, "The Editor's Own Page," The Ice Screamer, no. 37 (August 1988): 2.

"Market Trends," Postcard Collector 2 (December 1984): 30 .
} 


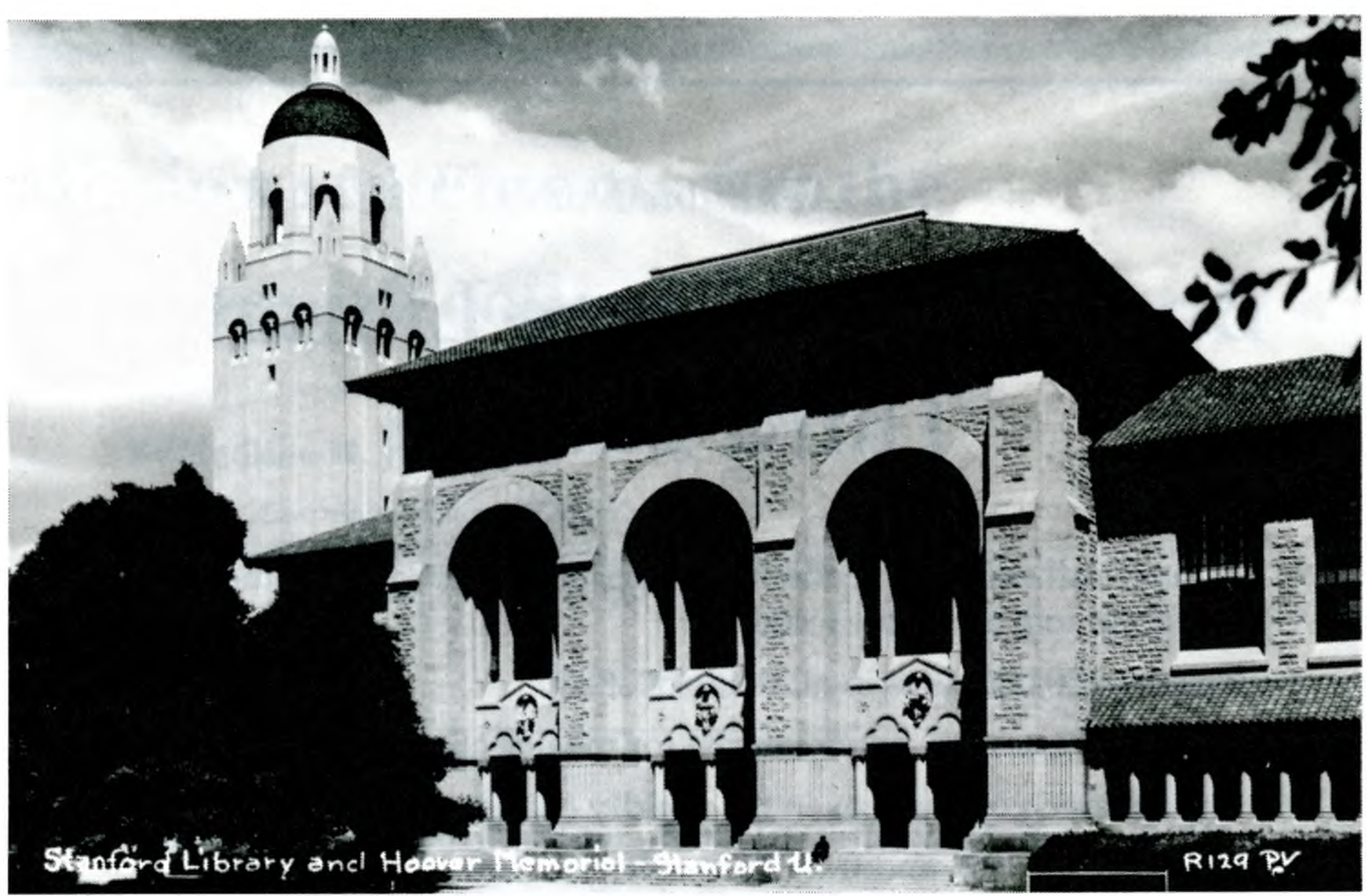

Fig. 6. Stanford University Library and Hoover Memorial, Stanford University.

dle price cards," that "linens are coming into their own," and "no let up in the demand for views" in $1985 .{ }^{8}$ "Record prices" for a large collection at auction were also recorded the same year."

By 1987, "bargains at shows" were described. ${ }^{10}$ It is still possible to purchase a library postcard for 25 cents at a flea market, but many are now $\$ 1.00$ or more.

The card's condition naturally has a bearing on its price. Space limitations prevent a discussion of how the condition of cards is described and the preservation, storage, and display of library postcards.

It is also not possible to regale you with a treatise on the messages found on library postcards. A keen observer of the postcard world has written that "the picture or verse is the first thing that a postcard collector looks for. Probably next is the stamp. Then, if at all interested, the message. When friends who are not collectors pick up one of your treasured cards, they invariably look at the message first and comment, 'I always like to read what people have to say." "11 You are, however, referred to the author's scholarly survey of messages on cards published earlier. ${ }^{12}$

There is space enough for a special plea, a promise, and a recommendation. Dear Reader: The author would welcome a postcard of your libraryacademic or otherwise-mailed to him at the Kuhn Library \& Gallery, UMBC, Baltimore, Maryland 21228. He will revive the custom of sending you one in return. He also promises the reader that an article will be forthcoming in this journal on those very scarce postcards: the interiors of academic libraries. Finally, he invites you to join the growing band of library postcard collectors. You can enjoy reading the message on the postcard only after you have had the other great pleasures of viewing the picture at great length, perusing the stamp, examining the condition of the card, and appraising its value to you.

8“Market Trends," Postcard Collector 3 (August 1985): 24 .

"Market Trends," Postcard Collector 3 (November 1985): 6 .

${ }^{10}$ "Market Trends," Postcard Collector 5 (September 1987): 6 .

${ }^{11}$ Marian Mulroy, "The Other Side of the Card: Postcard Messages," Postcard Collector 2 (July 1984): 24.

${ }^{12}$ Billy R. Wilkinson, "Library Postcards: The Messages," in Norman D. Stevens, A Guide to Collecting Librariana (Metuchen, N.J.: Scarecrow Press, 1986), 68-73.

\begin{tabular}{|l|}
\hline Clarifications \\
Eleanor L. Heishman, whose profile ap- \\
peared in the September 1988 issue of C $\bullet R L$ \\
News, was named director of libraries at the \\
State University of New York at Binghamton. \\
Rebecca Sturm, whose "Innovations" article, \\
"When Closing a Library Is Progress," appeared \\
in the September 1988 issue, is acting director of \\
the W. Frank Steely Library, Northern Ken- \\
tucky University, Highland Heights. \\
\hline
\end{tabular}




\section{Available Now! \\ Books for College Libraries, Third Edition}

- the most authoritative academic library collection development and evaluation tool available today

- more than 50,000 titles in all fields of study

- between $30 \%$ to $50 \%$ new material for most sections

- fully updated coverage even for rapidly changing fields

- more than 500 U.S. and Canadian college faculty and collection development librarians participated in title selection

Place your order early to receive the maximum discount! ISBN for the six-volume set: $0-8389-3353-X$.

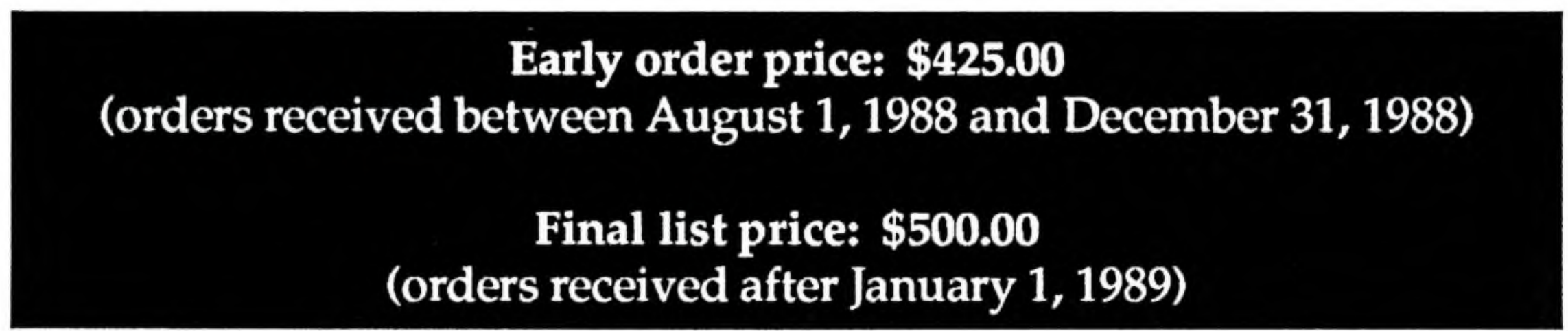

Individual volumes of BCL3 may also be purchased separately. Please contact the ALA Publishing Services Order Department for price and order information.

In addition to the print version, BCL3 will be available online and on magnetic tape. Requests for ordering information for tape and online versions should be addressed to BCL3/CHOICE, 100 Riverview Center, Middletown, CT 06457.

\section{American Library Association \\ 50 East Huron Street \\ Chicago, IL 60611}

